\title{
ECC
}

\section{DNA-based electrochemical biosensor using chitosan-carbon nanotubes composite film for biodetection of Pirazon}

\author{
Hossein Peyman*, Hamideh Roshanfekr, Sahar Ansari
}

Department of chemistry, Islamic Azad University, Ilam Branch, Ilam, Iran

Received: 13 April 2019, Accepted: 30 June 2019, Published: 1 November 2019

\begin{abstract}
The interaction of Pirazon (PIR) with calf thymus ds-DNA (double-stranded Deoxyribonucleic acid) in the solution and the immobilized DNA on chitosan-carbon nanotubes composite-modified gold electrode was investigated by electrochemical and UV-Vis spectroscopy techniques. In the solution interactions, spectroscopic results indicate non-intercalative binding of PIR. A competition study with methylene blue, as an intercalative probe, was applied to confirm the binding mode of PIR. PIR showed an oxidation peak at $1.1 \mathrm{~V}$ at the bare Au electrode. When ds-DNA was added into the PIR solution, its peak current decreased. Au electrode modified with single wall carbon nanotube (SWCNT) and chitosan (CS) decorated with the ds-DNA was tested to determine PIR content in solution. Electrochemical impedance spectroscopy (EIS) and cyclic voltammetry (CV) were used to characterize the electrochemical properties of the modified electrode. The modified electrode surface has good reproducibility and stability. The modified electrode exhibited linear detection range, $5 \times 10^{-9}$ to $5 \times 10^{-5} \mathrm{M}$, with a detection limit of $1 \times 10^{-10} \mathrm{M}$.
\end{abstract}

Keywords: Pirazon; DNA biosensor; SWCNT-CS composite.

\section{Introduction}

Although pesticides and herbicides have led to enhanced agricultural productivity in recent years, their release to the environment has made the problem of water quality a major concern at both national and international levels [1]. As required by the European Union, pesticide concentration in drinking water should not exceed $0.1 \mu \mathrm{g} \quad \mathrm{L}^{-1}$ for each compound or $0.5 \mu \mathrm{g} \mathrm{\textrm {L } ^ { - 1 }}$ for total pesticides [2].

Pirazon, [5amino-4-chloro-2phenylpyridazin $3(2 \mathrm{H})$-one] (PIR) is an herbicide widely used in agricultural areas. PIR is a selective systematic herbicide which inhibits photosynthesis, and it was used for general weeds control in the cultivation of sugar-beets, fodder beet and beet root (Figure 1) [3]. Moreover, its good solubility in water may lead to its leaching into the environment, thereby polluting both ground and surface water [4].

Different methods have been proposed in the literature for PIR detection, such as liquid chromatography [5], spectroscopy [6] 
and electrochemical methods [7]. Electrochemical biosensors are used as good tools for pollutants screening and detection as they are fast, simple, and cost-effective [8-10]. Electrochemical DNA biosensors encompass a nucleic acid recognition layer that is immobilized over an electrochemical transducer. The role of the nucleic acid recognition layer is either to detect the changes which occur in the DNA structure during interaction with DNAbinding molecules or to detect a specific sequence of DNA, selectively [11].

Generally speaking, electrochemical DNA biosensors can be used to study DNA interaction with different compounds over a wide potential range, at any ionic strength, and over a wide $\mathrm{pH}$ range. Molecules and ions interact with DNA in three meaningfully different ways: namely, electrostatic, groove binding (nonintercalation) and intercalation [12-19]. These reactions cause changes in the structure of DNA and base sequence, leading to the perturbation of DNA replication [20-21]. Today we know very well that DNA plays key role in cell proliferation, synthesis of proteins and transcription of genetic information in living cells. However, when the poison compounds interact with DNA, it may induce damaging and oxidative stress on DNA structure and therefore causes several diseases such as Parkinson's disease, prostitutes and childhood cancers [22-23].

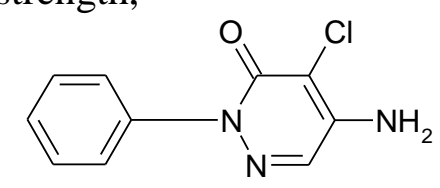

Figure 1. Scheme of PIR

In this context, the pesticides and herbicides should be considered as genotoxic and carcinogenic compounds [24].

Recently, nanomaterials have received increasing attention to design DNA biosensors due to their distinctive chemical and physical properties caused by quantum confinement, small size, and macro quantum tunnel effects [25-26]. As a common material, CNTs have been continually used as an ideal material to fabricate electrochemical biosensors since they were discovered in 1991 by Iijima [27]. However, lack of stability and uniformity of CNTs affect their direct immobilization on to the electrode surface. Therefore, CS has also been applied to improve DNA immobilization process [28-30].

Moreover, the low conductivity of these films leads to delay in electron transfer to some extent. To overcome the mentioned deficiency, the functionalized conductive polymers were electropolymerized on the surface of the electrode [31-33]. Nevertheless, the synthesis of the functionalized monomers has always been complicated, which consequently has limited its application. Hence, to improve the conductivity, films were doped with CNTs. CS-CNT film can be used to increase the electrochemical signal of the DNA indicator and the sensitivity of the biosensor. Also, CSCNTs can form a stable complex through non- covalent binding; the stability of CNTs in aqueous CS solution greatly improved [34]. In this report, we explore the interaction of PIR with DNA using spectroscopic and electrochemical methods in solution, and a DNA biosensor was constructed 
and used for the determination of PIR. For this purpose, a mixture of SWCNTs and CS was immobilized on the surface of a gold electrode (AuE) to improve the immobilization of ds-DNA on the surface. The signal of PIR after interaction with the ds-DNA was used for constructing the calibration curve and ultimately for quantitative inspections. It was found that the interaction between ds-DNA and PIR leads to the PIR preconcentration at the surface of the modified electrode and improves the detection limit of this method.

\section{Experimental}

\section{Chemicals}

The highly polymerized CT-DNA, SWCNT, PIR, and CS were purchased from Sigma Corp and used as received. Tris- $\mathrm{HCl}, \mathrm{NaCl}$, Methylene blue (MB), potassium ferro-/ferricyanide were purchased from Merck.

\section{DNA Binding Measurements and Instrumentation}

The stock solution of DNA $\left(1.0 \times 10^{-3}\right.$ M) was prepared according to our previous works [35,36]. Solutions of DNA in the Tris buffer $(10 \mathrm{mM}, \mathrm{pH}$ 7.4) gave the ratio of UV absorbance at 260 and $280 \mathrm{~nm}, \mathrm{~A}_{260} / \mathrm{A}_{280}$; of 1.9 indicating that the DNA was sufficiently free of protein. Concentrated stock solutions of DNA were prepared in the buffer. The concentration of DNA was measured using its extinction coefficient at 260 $\mathrm{nm}\left(6600 \mathrm{M}^{-1} \mathrm{~cm}^{-1}\right)$ after dilutions. Stock solutions were stored at $4{ }^{\circ} \mathrm{C}$ and were used no more than four days.

The Concentrated stock solution of PIR was prepared by dissolving it in $\mathrm{H}_{2} \mathrm{O}$ and diluting suitably with the corresponding buffer to the required concentrations for all of the experiments.
The UV-Vis spectra of the samples were recorded by lambda $25 \mathrm{UV}-\mathrm{V}$ is spectrophotometer. In a typical experiment, $3 \mathrm{ml}$ solution of CT-DNA $\left(5.0 \times 10^{-5} \mathrm{M}\right)$ was transferred into a cuvette. Absorbance titration was conducted by adding concentrated stock solutions of PIR $\left(1.0 \times 10^{-3} \mathrm{M}\right)$ directly to the cuvette. UV-visible spectra were recorded in the range of $200-350 \mathrm{~nm}$ about 5 min after each addition of PIR solution.

For competition studies with methylene blue (MB), $3 \mathrm{~mL}$ solution of MB $\left(5.0 \times 10^{5} \mathrm{M}\right)$ was transferred into a cuvette. Absorbance titration was conducted by adding the concentrated stock solutions of CT-DNA $\left(1.0 \times 10^{-3}\right.$ M) directly to the cuvette. This solution was allowed to stand for $5 \mathrm{~min}$, and then spectrophotometric data were collected from solutions of different DNA concentrations. Then, different amounts of PIR solution were added to a series of solution containing $\mathrm{MB}$ and DNA.

All voltammetric experiments were performed in a single-compartment cell with a three-electrode configuration on an Autolab Type 204 potentiostat/galvanostat, with a threeelectrode system containing: modified $\mathrm{Au}$ electrode (Metrohm electrode $3 \mathrm{~mm}$ diameter) as working electrode, an $\mathrm{Ag} / \mathrm{AgCl}$ electrode as a reference electrode, and $\mathrm{Pt}$ wire as counter electrode. Electrochemical experiments were carried out in a $25 \mathrm{~mL}$ voltammetric cell at room temperature. All potentials are referred to the $\mathrm{Ag} / \mathrm{AgCl}$ reference. $\mathrm{Au}$ electrode surfaces were freshly polished with $0.05 \mathrm{~mm}$ alumina before each experiment and were rinsed using double distilled water between each polishing step. The supporting electrolyte was $10 \mathrm{mM}$ of Tris buffer solution ( $\mathrm{pH}$ 7.4) which was prepared 
with double distilled water. CV measurements were recorded by keeping the concentration of PIR constant $\left(5.0 \times 10^{-5} \mathrm{M}\right)$ while varying the DNA concentration from 0.0 to $5.0 \times 10^{-}$ ${ }^{5} \mathrm{M}[37,38]$.

\section{Preparation of CS-CNTs nanocomposite modified electrode}

CS-CNTs nanocomposite was prepared according to literature methods [39]. Briefly, SWCNTs was dispersed in 4.0 $\mathrm{M} \mathrm{HCl}$ for $4 \mathrm{~h}$ under ultrasonic agitation. The solid product was carefully rinsed with water to have a neutral $\mathrm{pH}$ and, then, dried, after that the $\mathrm{CNT}_{\mathrm{S}}$ were dispersed in $60 \mathrm{ml}$ mixture of concentrated nitric acid and sulfuric acid (1:3) with ultrasonic agitation for $4 \mathrm{~h}$ in da water bath followed by washing until $\mathrm{pH}$ turned to be natural and finally it was dried. Dispersion in acids was applied to eliminate metal oxide catalysts. A $2 \%$ (W/V) CS solution was prepared in $1 \%$ acetic acid. Then $1.5 \mathrm{mg}$ of SWCNT was dissolved in CS solution and ultrasonicated for $2 \mathrm{~h}$ to obtain a uniform mixture. With the dipping of freshly polished AuE in CS-CNT solution, the modified electrode was fabricated that is noted as CSCNTs/AuE. In this way, a robust CS film doped with CNTs was formed.

\section{DNA immobilization}

To prepare single-stranded DNA, the double-stranded DNA was heated in a water bath at $100{ }^{\circ} \mathrm{C}$ for $30 \mathrm{~min}$ and cooled in an ice bath immediately [40]. To obtain the DNA-modified CS$\mathrm{CNTs} / \mathrm{AuE}, 5 \mu \mathrm{L}$ of ds-DNA solution was pipetted on the surface of the CSCNT/AuE. After air drying, the electrode was rinsed thoroughly with buffer to eliminate the unbounded DNA. Thus, the DNA-modified electrode (ds-DNA/CS-CNTs) was designed.
Interaction between $d s-D N A$ and PIR at the ds-DNA-modified electrode

To inspect the interaction between PIR and ds-DNA, the ds-DNA-modified AuE was immersed in to stirred Tris buffer solution ( $\mathrm{pH}$ 7.4) containing different concentrations of PIR. After the accumulation step, the ds-DNA modified AuE was rinsed and differential pulse voltammograms were recorded.

\section{Results and discussion}

Interaction between PIR and DNA in solution

\section{Absorption Titration}

Electronic absorption spectroscopy is universally employed to determine the binding characteristics of compounds with DNA [41-43,44]. The B-form of CT-DNA is a polyanion containing two complementary polymeric subunits hydrogen bonded together in the form of a right-handed double helix [45].

If a compound has a strong interaction with DNA, it could create a hyperchromic or hypochromic effect in DNA spectra. "Hyperchromic effect'" and "hypochromic effect" are the spectra features of DNA concerning its double-helix structure [46]. This spectral change process reflects the corresponding changes of DNA in its conformation and structures after the compound bound to DNA. Hypochromism results from the contraction of DNA in the helix axis, as well as from the change in conformation on DNA, while hyperchromism results from the damage of the DNA double helix structure [46]. Our results show a typical "hypochromic effect" (Figure $2)$. This kind of binding may have caused a slight change of the conformation of DNA [47]. 


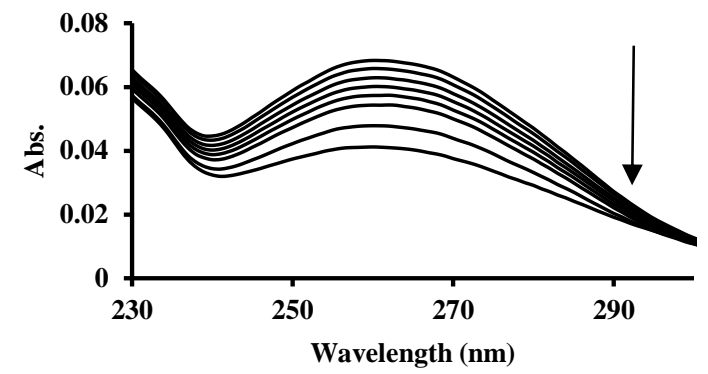

Figure 2. Absorption spectra of $5 \times 10^{-5} \mathrm{M}$ of ds-DNA in absence and presence of addition of PIR with $\mathrm{r}_{\mathrm{i}}=[\mathrm{PIR}] /[\mathrm{DNA}]=0,0.5,0.8,1,1.2,1.5,1.8,2$
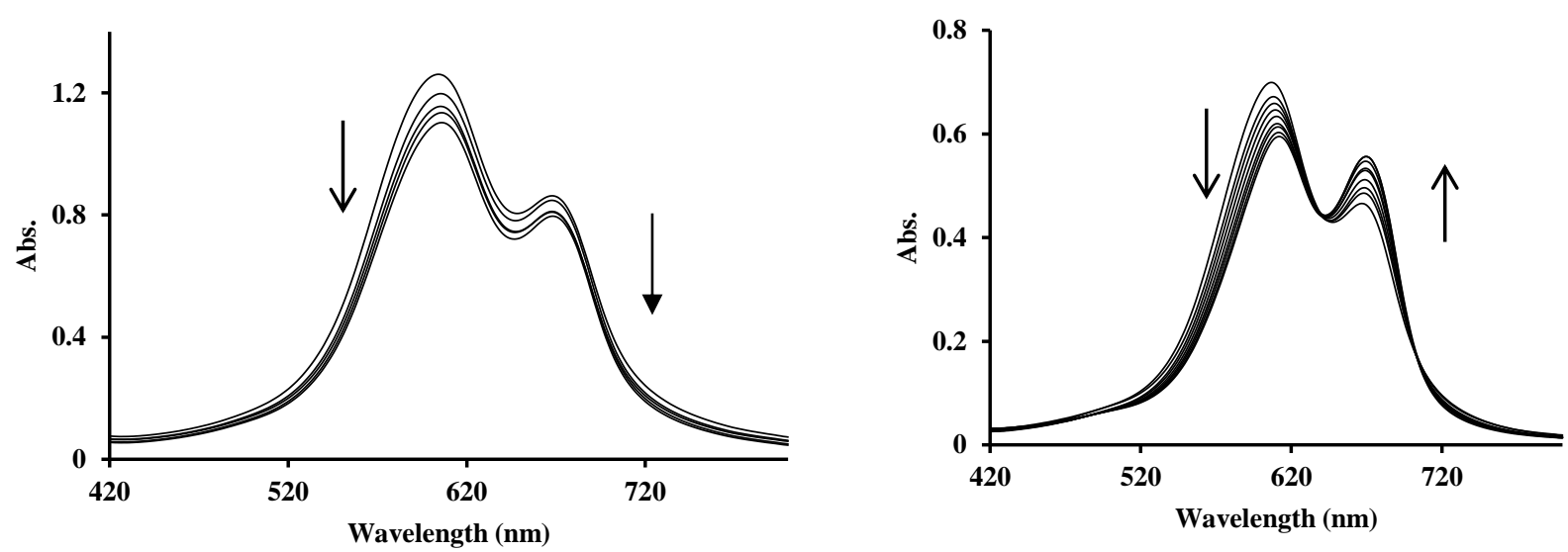

Figure 3. Absorption spectra of $\mathrm{MB}$ in absence and presence of DNA in $\mathrm{r}_{\mathrm{i}}=[\mathrm{DNA}] /[\mathrm{MB}]=0.5$, $0.75,1,1.25,1.5,1.75,2,2.25, \mathrm{C}_{\mathrm{MB}}=5 \times 10^{-5} \mathrm{M}$. Inset: Absorption spectra of MB-DNA in absence and presence of PIR with $\mathrm{r}_{\mathrm{i}}=[\mathrm{MB}-\mathrm{DNA}] /[\mathrm{PIR}]=1,1.5,2,2.5, \mathrm{C}_{\mathrm{MB}}=5 \times 10^{-5} \mathrm{M}, \mathrm{C}_{\mathrm{DNA}}=25 \times 10^{-5} \mathrm{M}$

\section{Methylene blue (MB) displacement study}

Competitive binding studies with MB were carried out to provide another support for the mode of binding of PIR with DNA. When MB interacts with DNA, it intercalates into the base pairs of the DNA. Absorption spectra of MB dye in the absence of DNA showed two bands at maximum wavelengths of 610 and $670 \mathrm{~nm}$. With increasing the concentration of CT-DNA, the absorption at wavelengths of 610 and $670 \mathrm{~nm}$ gradually decreased and increased, respectively (Figure 3A). By addition different concentrations of PIR to the solution containing methylene blue and DNA, a competition occurred between PIR and MB. As it has clearly shown (Fig. 3B), the intensity of MB-
DNA spectra bands decrease at both wavelengths. If a molecule could insert between DNA bases and be able to replace the $\mathrm{MB}$, the spectra of free $\mathrm{MB}$ will be recovered. It was shown after addition of PIR to MB-DNA solution; there was no complete recovery in the MB peaks (610 and $670 \mathrm{~nm}$ ). This finding indicated that PIR couldn't insert between DNA bases that is indicative of its non-intercalative mode of binding [11].

Interaction of PIR with DNA on CSCNT modified electrode

Characterization of the DNA/CNT-CS film

SEM is an excellent tool for studying the surface morphology of thin films on nano-scale. Figure 4 shows the SEM amplitude images of the unmodified $\mathrm{Au}$ 
electrode and CNT-CS modified $\mathrm{Au}$ electrode surfaces. The surface roughness of the unmodified $\mathrm{Au}$ electrode is seen in Figure 4A, clearly. Randomly of the obtained SWCNT could be seen from the SEM are covered uniformly on the entire surface of the Au electrode. Positively charged $\mathrm{CS}$ is easily coated on the negatively charged surface of the SWCNTs by electrostatic interaction (Figure 4B). CS molecules can considerably combine with negatively charged DNA to from DNA films because it is a strong linear cationic polyelectrolyte. As shown in the SEM image Fig. 4B, DNA molecules are aggregated and saturated on the CNTs-CS [46].

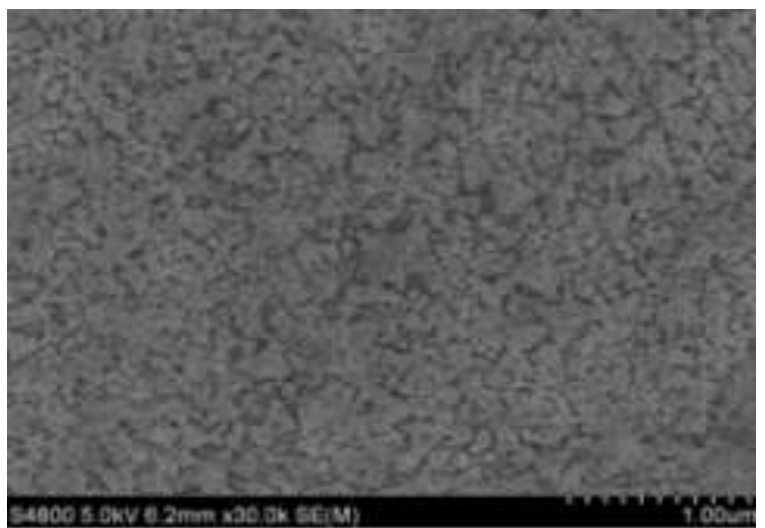

a

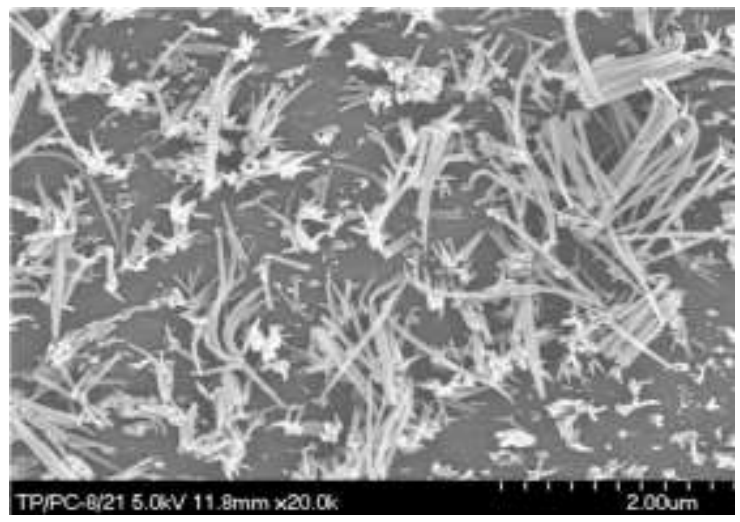

b

Figure 4. SEM images of a) unmodified AuE, b) DNA/CNTs-CS modified AuE

The redox peak currents in the CV of the redox indicator $5 \mathrm{mM}$ $\left[\mathrm{Fe}(\mathrm{CN})_{6}\right]^{3-/ 4-}$ at the bare, CS-CNTs, dsDNA/CS-CNT modified AuE (Figure 5A) were evaluated as basic parameters to characterize the electrode surface. CVs were recorded at a scan rate of $100 \mathrm{mV} / \mathrm{s}$. At the bare AuE, a pair of reversible redox peaks assigned to the electron transfer between $\mathrm{Fe}(\mathrm{CN})_{6}{ }^{3-}$ and $\mathrm{Fe}(\mathrm{CN})_{6}{ }^{4-}$ were observed clearly (curve a). When the electrode was modified with the CS-CNTs nanocomposite, the redox peak currents of $\mathrm{Fe}(\mathrm{CN})_{6}{ }^{3-} / \mathrm{Fe}(\mathrm{CN})_{6}{ }^{4-} \quad$ increased sharply, as expected. Also, the peak to peak separation decreased (curve b), which reveals that the presence of CNTs in the modification layer dramatically promoted the electron transfer of the electroactive molecules at the electrode surface. When DNA was adsorbed on the CS-CNT film, the cathodic peak current of the $\left[\mathrm{Fe}(\mathrm{CN})_{6}\right]^{3-}$ $/\left[\mathrm{Fe}(\mathrm{CN})_{6}\right]^{4-}$ redox indicator decreased (curve c) because DNA with a negative charge could retard the redox indicators to the electrode surface. Thus, the decrease of the peak current of ferricyanide indicated the formation of the DNA/CS-CNT film at the electrode surface, which is indicative of lesser access of the redox indicator to the modified electrode surface [47]. Impedance spectroscopy was also used to identify the effect of the modification. Fig. 5B shows the impedance spectra of the unmodified AuE, SWCNT-CS modified AuE, and ds-DNA/SWCNT-CS modified AuE in $5.0 \mathrm{mM} \mathrm{Fe}(\mathrm{CN})_{6}{ }^{3-/ 4-}(1: 1)$ containing $0.1 \mathrm{M} \mathrm{KCl}$. As compared to the unmodified AuE, a smaller semi-circle at higher frequencies was observed at SWCNTs-CS/AuE. This indicated that the impedance of the electrode decreased obviously in the presence of the SWCNTs-CS nanocomposite which may have promoted the electronexchange between $\mathrm{Fe}(\mathrm{CN})_{6}{ }^{3-/ 4-}$ andthe 
electrode. The charge transfer resistance, $\mathrm{R}_{\mathrm{ct}}$, indicating the diameter of the semicircle for dsDNA/SWCNTs-CS biosensor, is higher than that of the electrode without

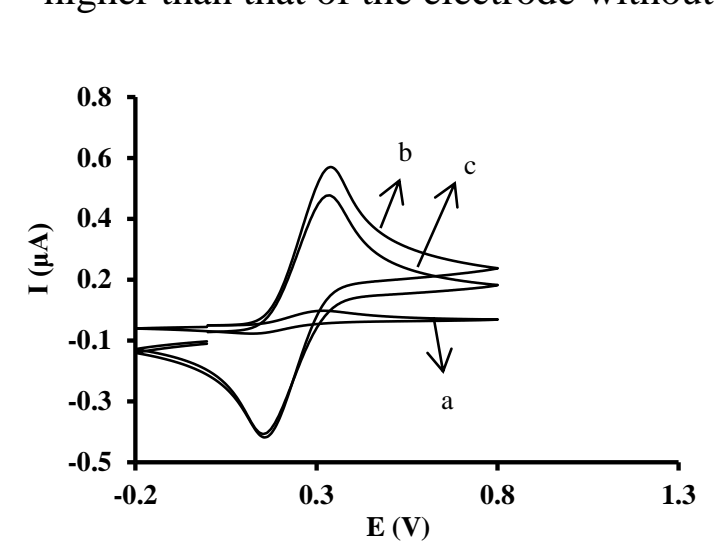

A
DNA because its negatively charged interface represents an electrostatic barrier toward the anions of the redox indicator.

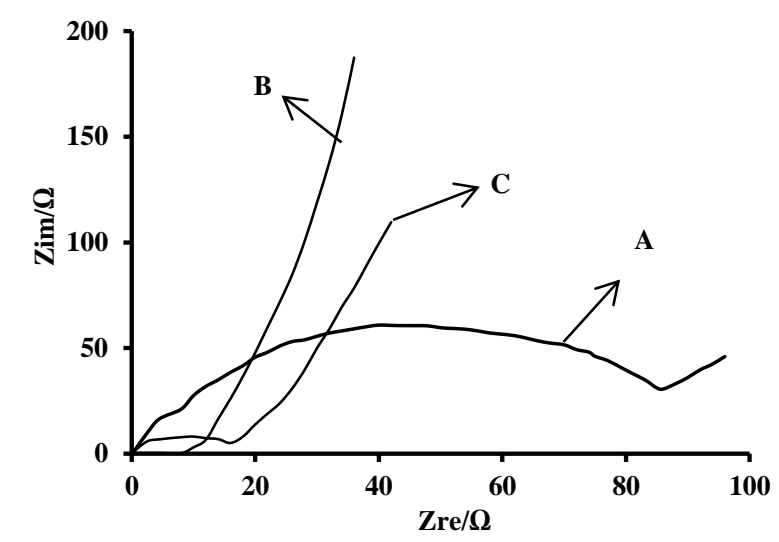

B

Figure 5. A) $\mathrm{CV}$ of different modified electrodes in $0.1 \mathrm{M} \mathrm{KCl}$ solution containing $0.02 \mathrm{M}$ $\mathrm{K}_{3}\left[\mathrm{Fe}(\mathrm{CN})_{6}\right]$ in scan rate $0.1 \mathrm{~V} / \mathrm{s}$, a) bare AuE, b) SWCNT/CS AuE, c) SWCNT/CS/DNA AuE. B) Nyquist relationship of EIS data performed in a $0.1 \mathrm{M} \mathrm{KCl}$ solution containing $0.01 \mathrm{M}[\mathrm{Fe}(\mathrm{CN}) 6]^{3-14}$, in scan rate of $0.1 \mathrm{~V} / \mathrm{s}$ a) bare AuE, b) SWCNT/CS AuE, c) SWCNT/CS/DNA AuE
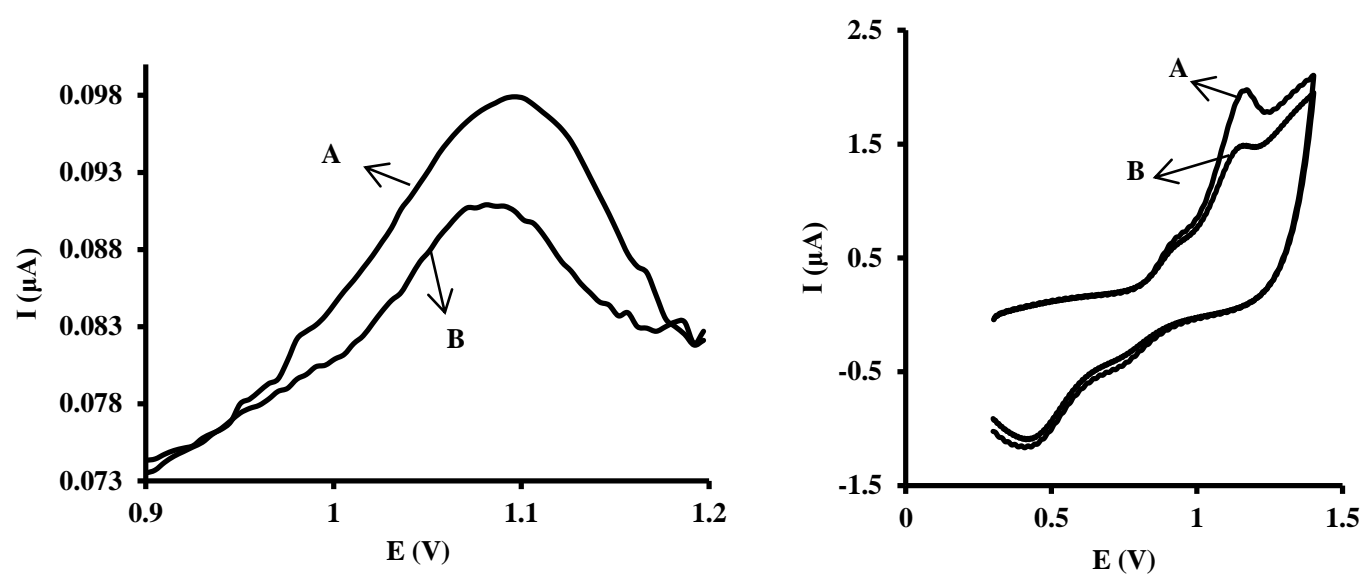

Figure 6. A) DPV curves of $5 \times 10^{-5} \mathrm{M}$ PIR at bare electrode (curve a) and SWCNT/CS/DNA Au electrode (curve b) in $\mathrm{pH}$ 7.4. B) $\mathrm{CV}$ curve in $0.01 \mathrm{M}$ Tris-HCl containing PIR $5 \times 10^{-5}$ at, a) bare Au, b) SWCNT/CS/ds DNA AuE

Interaction of PIR with ds-DNA

Figure 6A shows the differential pulse voltammetric (DPV) responses of $5 \times 10^{-}$ ${ }_{5} \mathrm{M}$ PIR at both bare AuE and dsDNA/SWCNT-CS/AuE. PIR has a redox reaction with Scheme 1 mechanism [48]. The peak current obtained at DNA/SWCNT-CS/AuE is higher than obtained with the bare AuE.
The increase in the peak current indicated that PIR could interact with the ds-DNA immobilized on the AuE surface. Moreover, Figure 6B shows the $\mathrm{CV}$ peaks of PIR on bare and modified electrodes. It can be seen again that the background current of PIR on modified AuE is much larger than of the bare AuE, which may be 
due to the electro catalytic activity of CNT-CS/ds-DNA AuE on PIR. The surface area of CNT-CS/ds-DNA AuE must be greater than the bare AuE, which also results to the increase of peak current. The results showed that the ds-DNA modified surface was more favorable for PIR molecules to undergo redox reaction than the bare $\mathrm{AuE}$ surface. This finding indicates a preconcentration of PIR on the DNAmodified surface due to its binding to ds-DNA.

Comparison of the interactions of $d s$ DNA and ss-DNA with PIR

To study the denaturation of DNA, $1.0 \times 10^{-5} \mathrm{M}$ of ds-DNA and ss-DNA were added into the Tris- $\mathrm{HCl}$ buffer solution, containing $5.0 \times 10^{-5} \mathrm{M}$ PIR and DPV signals which were recorded at the unmodified AuE. As shown in Figure 7, although the peak currents decreased in both cases, the peak current of PIR fell more sharply with ds-DNA. This result demonstrated a more intense interaction of PIR with dsDNA, which might be the result of the stronger binding nature between PIR and ds-DNA or the increasing blockage of the electron transfer of PIR through the electrode surface by ds-DNA absorption, or probably both. The distinct difference in DPV behaviors of PIR could be used to distinguish dsDNA from ss-DNA $[49,50]$.

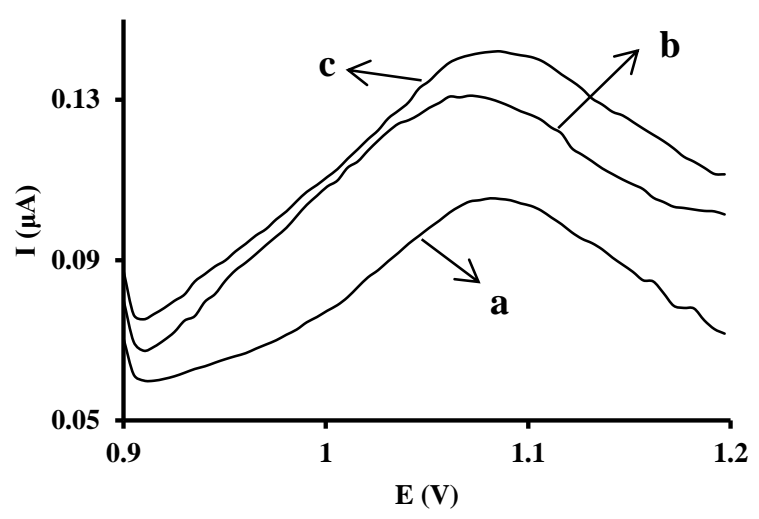

Figure 7. $\mathrm{DPV}_{S}$ of PIR at the unmodified AuE in Tris- $\mathrm{HCl}$ buffer (0.1 M at $\left.\mathrm{pH} 7.4\right)$, a) $5 \times 10^{-5} \mathrm{M}$ PIR, b) $5 \times 10^{-5} \mathrm{M}$ PIR and $10^{-5} \mathrm{M}$ ss-DNA, c) $5 \times 10^{-5} \mathrm{M}$ PIR and $10^{-5} \mathrm{M}$ ds-DNA

\section{Selection of optimum experiment} conditions

To construct DNA/CNT-CS modified AuE, different variable such as immobilization time of CNT-CS on the $\mathrm{AuE}$, amount of CNT and concentration of ds-DNA were optimized.

To optimize the immobilization time of CNTs-CS, the pretreated AuEs were dipped into the SWCNTs-CS composite for $30,60,90$, and $120 \mathrm{~min}$. The results showed that a dramatic increase occurred in the oxidation peak currents of PIR during the immobilization time up to 90 min after which the currents were almost leveled off over longer immobilization times. So, $90 \mathrm{~min}$ was selected as the immobilization time of CNTs and CS on the AuE. With increasing of CNTCS immobilization time on the electrode surface, more composite placed on surface that leads to more surface area and more electron transfer. After 90 min, the electrode surface was saturated and more immobilization time does not affect on the signal. 
To check the influence of the amount of CNTs on the sensitivity of the CNT-CS modified electrode, the CNT content in CNT-CS composite was varied between 0.5 to $2 \mathrm{mg}$. The results showed that the oxidation peak current increased with increasing CNTs content up to $1.5 \mathrm{mg}$, but decreased beyond that. Therefore, $1.5 \mathrm{mg}$ of CNTs was selected and used in all further experiments. With increasing CNT content in CNT-CS composite, the surface area was increased, and because of better electron conductivity, the peak current was increased. However, more increasing of CNT, because of aggregation and ununiformity, doesn't increase the peak current.
The optimum condition for the dsDNA concentration was found to obtain the maximum PIR signal. To find the optimum concentration of ds-DNA, different concentration of ds-DNA were used. The result showed that the peak current increased by increasing dsDNA concentration up to $5.0 \times 10^{-5} \mathrm{M}$, beyond which it leveled off. Therefore, $3.0 \times 10^{-5} \mathrm{M}$ of ds-DNA was selected as the optimum concentration (Figure 8). DNA molecules prepare suitable acceptor cites for PIR molecules on the electrode surface, so with increasing in DNA concentration, more cites are available for analytes and the peak current increases. Aggregation of DNA molecules at high concentration decreases the synergic effect with CNT on electron transfer.

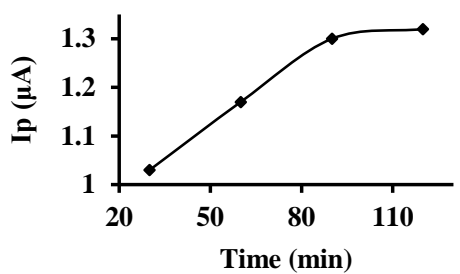

A

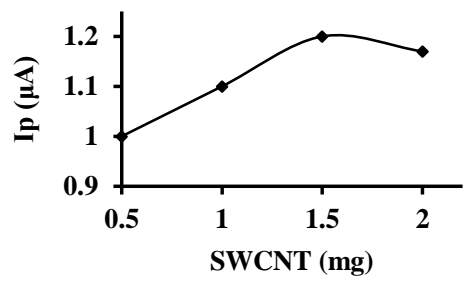

B

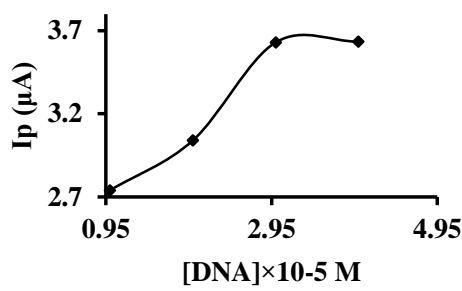

C

Figure 8. A) The study immobilization time of SWCNT-CS on AuE (SWCNT $=1 \mathrm{mg}, \mathrm{DNA}=10^{-5} \mathrm{M}$, $\left.\left.\mathrm{PIR}=5 \times 10^{-5} \mathrm{M}\right), \mathrm{B}\right)$ Study the influence of the amount SWCNT (Time $=90 \mathrm{~min}, \mathrm{DNA}=10^{-5} \mathrm{M}$, $\left.\left.\mathrm{PIR}=5 \times 10^{-5} \mathrm{M}\right), \mathrm{C}\right)$ Study the influence of the amount DNA $(\mathrm{SWCNT}=1.5 \mathrm{mg}$, Time $=90 \mathrm{~min}$, $\left.\mathrm{PIR}=5 \times 10^{-5} \mathrm{M}\right)$

Study of the linear range of biosensor responses

Figure 9 demonstrates the effect of different concentrations of PIR on the biosensor response. It was shown the current responses increase with increasing the PIR concentrations that indicates more PIR accumulation. This current response was linear towards the PIR concentrations of $5.0 \times 10^{-9} \mathrm{M}$ to $5.0 \times 10^{-5} \mathrm{M}$ with LOD $\left(3 \mathrm{~S}_{\mathrm{b}} / \mathrm{m}\right) 1.0 \times 10^{-}$ 10 M. Good obtained LOD in this method is noteworthy. Most of herbicides measurements are based on chromatography techniques and so far, the use of DNA biosensors for detection of herbicides has not been reported (Table 1). It seems this is due to the stronger matrix effects and difficulties in chromatographic separation, resulting in a higher uncertainty of measurements [51-55]. 
Table 1. The analytical performances for PIR detection by various methods

\begin{tabular}{|c|c|c|c|}
\hline Method & Linear Range $(\boldsymbol{\mu M})$ & Detection Limit & Reference \\
\hline $\mathrm{LC}^{1}-\mathrm{ESI}^{2}-\mathrm{TMS}^{3} / \mathrm{QUEChERS}$ & - & $0.8(\mu \mathrm{g} / \mathrm{L})$ & 51 \\
\hline UPLC $^{4}-E S I-M S^{5} / M S$ & - & $0.01(\mu \mathrm{g} / \mathrm{L})$ & 52 \\
\hline HPLC $^{6}$ & - & $3.5(\mu \mathrm{g} / \mathrm{Kg})$ & 53 \\
\hline $\mathrm{GC}^{7}$ & - & $0.4(\mu \mathrm{g} / \mathrm{Kg})$ & 54 \\
\hline FSDPV $^{8}$ & $0.1-1.0$ & $0.006(\mu \mathrm{g} / \mathrm{L})$ & 55 \\
\hline Present work & $0.005-50$ & $0.01 / \mathrm{L})$ & - \\
\hline
\end{tabular}

1. Liquid Chromatography 2. Electrospray Ionisation Spectrometry 3.Tandem Mass spectrometry 4. UltraPerformance Liquid Chromatography 5. Mass Spectrometry 6. High Performance Liquid Chromatography 7. Gas Chromatography 8. Fast-Scan Differential Pulse Voltametry

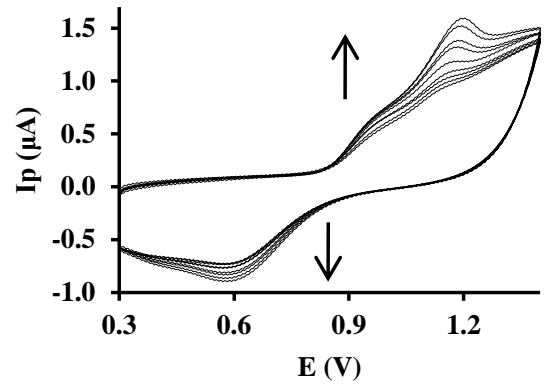

A

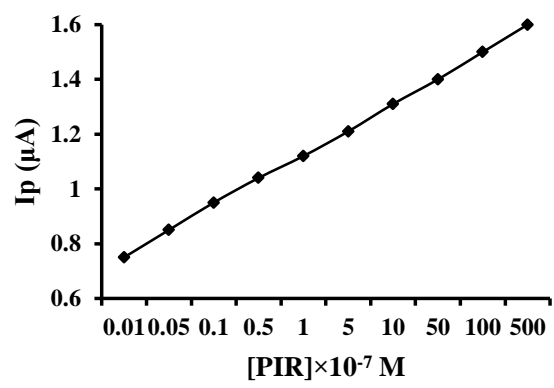

B

Figure 9. A) CV of different concentration of PIR interaction with ds-DNA, B) The linear response range of the biosensor

Electrode repeatability and stability

The ds-DNA/SWCNT-CS/AuE can be used for the determination of PIR. The repeatability of DNA biosensor was assessed by repeating the measurements in $0.01 \mathrm{mM}$ PIR ( $\mathrm{pH} \mathrm{7.4)} \mathrm{using} \mathrm{one}$ modified electrode during one week. The standard deviation was $2.93 \%$ $(n=6)$ (Figure 10). When the modified electrode stored at $4{ }^{\circ} \mathrm{C}$ for more than one week, the response current of the DNA biosensor slightly decreased.

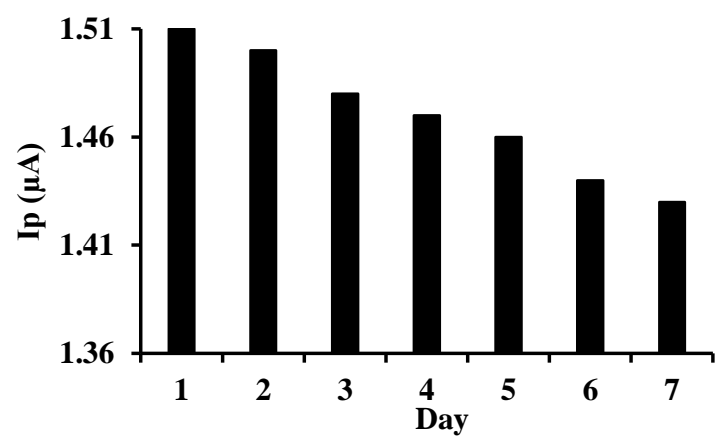

Figure 10. Pick current of DNA biosensor in different days 


\section{Real sample analysis}

Due to the penetration of pesticides and herbicides on groundwater resources, the wells water of Ilam city were selected as a real sample to test the practical application of the DNA biosensor. The assayed samples were also studied using the standard addition method without any pretreatment. For the standard addition method water samples were prepared by addition PIR before each treatment. Water samples were spiked with a known amount of PIR and RSD measurements were made. The amount of PIR was obtained $1.04 \mu \mathrm{M}$ and RSD in this method was $3.01 \%(\mathrm{n}=5)$ (Table 2).

Table 2. PIR Determination of in well water samples

\begin{tabular}{ccccc}
\hline Sample & Spiked level $(\boldsymbol{\mu M})$ & Found $(\boldsymbol{\mu M})$ & RSD $(\%)$ & Recovery $^{*}(\%)$ \\
\hline \multirow{2}{*}{ Well } & 0.00 & 1.04 & 3.01 & - \\
Water & 0.5 & 1.55 & 2.97 & 102 \\
$* \mathrm{n}^{2}=5$ & 1.5 & 2.53 & 3.07 & 98 \\
\hline
\end{tabular}

\section{Interference study}

The selectivity of the sensor was studied in the presence of $\mathrm{Ca}^{+2}, \mathrm{Mg}^{+2}$ ions, Bentazone and Terbuthylazine herbicides. The mention compounds were added to the solution in turn and DPV responses were investigated.

The results are shown in Table 3. The responses show considerable selectivity to pyrazon.

Table 3. Effect of interferences of the recovery of the analyte (10 ppm, $\mathrm{n}=5)$

\begin{tabular}{ccc}
\hline Interference & Concentration $\mathbf{( p p m )}$ & Recovery $\mathbf{( \% )}$ \\
\hline $\mathrm{Ca}^{2+}$ & 1000 & $98 \pm 2$ \\
$\mathrm{Mg}^{2+}$ & 1200 & $97 \pm 1$ \\
Bentazone & 40 & $101 \pm 2$ \\
Terbuthylazine & 80 & $103 \pm 1$ \\
\hline
\end{tabular}

\section{Conclusion}

Highly sensitive biosensors for the determination of herbicides in the environment and drinking waters are particularly interesting. In this study, the PIR interaction with DNA was investigated by electrochemical and spectroscopic methods. Our findings revealed a considerable interaction between PIR and ds-DNA.

CS as a polycation and SWCNTs provide a surface with positive charges and a high surface area for the immobilization of ds-DNA as a polyanion. Using the DNA/SWCNTs$\mathrm{CS} / \mathrm{AuE}$ electrode, we were able to detect the interaction of PIR with ds-
DNA, which allowed us to apply a DNA-modified electrode for ultra-trace determination of PIR. PIR can be preconcentrated in immobilized dsDNA due to the binding to double helix of the ds-DNA, which increases the differential pulse oxidation wave of PIR higher than that of the bare electrode. This result means that PIR achieved a preconcentration more times higher than that when it could reach in the absence of ds-DNA.

The spectroscopic results show that PIR may interact with DNA via non intercalation mode. The direct electrochemical behavior of 
immobilized ds-DNA on SWCNT modified Au electrode as a biosensor was studied for detection of DNA interaction with PIR. The modified electrode has shown significantly improved properties to the measurement of PIR compared with unmodified electrodes (bare). The modified electrode successfully for the detection trace amount of PIR is used in the interaction with DNA. Moreover, this method is fast, simple, sensitive, and cost-effective for the identification and evaluation of PIR.

\section{Acknowledgments}

The authors wish to thank the Islamic Azad University of Ilam for supporting this research. For this research project, we benefited from the sponsorship of the Islamic Azad University of Ilam.

\section{References}

[1] M. Chicharro, M. Moreno, E. Bermejo, S. Ongay, A. Zapardiel, $J$. Chromatogr. A, 2005, 1099, 191-197.

[2] M. Chicharro, A. Zapardiel, E. Bermejo, Moreno, Talanta, 2003, 59, 3745.

[3] C. Tomlin, Crop Protection Publications, 1994, 1341.

[4] F. Flores-Céspedes, M. VillafrancaSanchez, S. Pérez-Garcia, M. FernandezPérez, Chemosphere, 2007, 69, 785-794.

[5] Y. Sun, P. Filio, D. Wang, J. Qiang li, Y. Song Cao, J. Agric, Food Chem. 2009, 57, 4540-4544.

[6] W. Weber, W. Seitz, W. Schulz, H. A. Wagener, Vom Wasser, 2007, 105, 334.

[7] J. M. Zen, H. P. Chen, A. Senthil Kumar, Anal. Chim. Acta, 2001, 449, 95102.

[8] S. Takeda, K. Fukushi, K. Chayama, Y. Nakayama, Y. Tanaka, Sh. Wakida, $J$. Chromatogr. A, 2004, 1051, 297-301.

[9] I. Bobeldijk, K. Broess, P. Speksnijder, T. van Leerdam, $J$. Chromatogr. A, 2001, 938, 15-22.
[10] Y. Sun, L. Luo, F. Wang, J. Li, Y. Cao, Anal. Bioanal. Chem. 2009, 395, 465-471.

[11] S. Kashanian, M. M. Khodaei, H. Roshanfekr, H. Peyman, Spectro chimica Acta: part A, 2013, 114, 642-649.

[12] S. Kashanian, N. Shahabadi, H. Roshnfekr, K. Shalmashi K. Omidfar, Biochemistry, 2008, 73, 929-936.

[13] N. Shahabadi, S. Kashanian, K. Shalmashi, H. Roshnfekr, Appl Biochem Biotechnol. 2009, 58, 1-10.

[14] S. Kashanian, M. M. Khodaei, H. Roshanfekr, N. Shahabadi, A. Rezvani, Gh. Mansouri, DNA Cell. Biol. 2011, 30, 287-296.

[15] M. G. Gholivand, S. Kashanian, H. Peyman, H. Roshanfekr, Eur. J. Med. Chem., 2011, 46, 2630-2638.

[16] S. Kashanian, M. M. Khodaei, H. Roshanfekr, N. Shahabadi, Gh. Mansouri, Spectrochimica Acta: part A, 2012, 86, 351-359.

[17] S. Kashanian, Z. Shariati, H. Roshanfekr, S. Ghobadi, DNA. Cell. Biol. 2012, 31, 1341-1348.

[18] S. Kashanian, A. Tahmasian Ghobadi, H. Roshafekr, Z. Shariati, Mol. Biol. Report, 2013, 40, 1173-1179.

[19] S. Kashanian, M. M. Khodaei, H. Roshanfekr, Gh. Mansouri, Mol. Biol. Report, 2014, 41, 25-37.

[20] E. Mirmomtaz, A. A. Ensafi, Electrochem, 2009, 54, 4353-4358.

[21] A. A. Ensafi, E. Heidarbafrooei, M. Amini, Biosens. Bioelectron, 2012, 31, 376-381.

[22] M. Ladau-Ossondo, N. Rabia, J. JosPalage, L. M. Marquet, Y. Isidor, C. Saint-Aime, M. Martin, P. D. Irigaray, Biomed. Phamacol, 2009, 63, 383-395.

[23] M. Nasterlack, Int, J. Hyg, Environ Health, 2007, 210, 645-657.

[24] M. Borzsonyi, A. Pinter, A. Surjan, G. Torok, Cancer Lett. 1978, 5, 107-113. [25] G. Fagas, G. Tkachov, A. Pfund, K. Richter, Phys. Rev. B, 2005, 71, 224510224520. 
[26] E. V. Shevchenko, M. I. Bodnarchitk, M. V. Kovalenko, D. V.; Talapin, R. K. Smith, S. Aloni, A. W. Heiss, A. P. Alivisatos, Adv. Mater. 2008, 20, 4323-4329.

[27] S. Iijima, Nature, 1991, 354, 56-58. [28] C. Xu, H. Cai, Q. Xu, P. G. He, Y. Z. Fang, J. Anal. Chem. 2001, 369, 428432.

[29] N. N. Zhu, A. P. Zhang, Q. J. Wang, P. G. He, Y. Z. Fang, Anal. Chim. Acta, 2004, 510, 163-168.

[30] SC. G. Hu, S. S. Hu, Electrochim. Acta, 2004, 49, 405-412.

[31] L. A. Thompson, J. Kowalik, M. Josowicz, J. Janata, J. Am. Chem. Soc. 2003, 125, 324-325.

[32] T. Y. Lee, Y. B. Shim, Anal. Chem. 2001, 73, 5629-5632.

[33] P. A. Johnson, M. A. Gaspar, R. Levicky, J. Am. Chem. Soc. 2004, 126, 9910-9911.

[34] M. Zhang, W. Gorski, J. Am. Chem. 2005, 127, 2058-2059.

[35] S. Kashanian, M. M. Khodaei, H. Roshanfekr, N. Shahabadi, A. Rezvani, Gh. Mansouri, DNA Cell Biol. 2011, 30, 287-296.

[36] S. Kashanian, M. M. Khodaei, H. Roshanfekr, N. Shahabadi, Gh. Mansouri, Spect. Chim.Acta. 2012, 86, 351-359.

[37] Y. Ni, D. Lin, S. Kokat, Anal. Biochem, 2006, 352, 231-242.

[38] M. B. Gholivand, S. Kashanian, H. Peyman, Spectrochim. Acta, Part A, 2012, 87, 232-240.

[39] Q. Wang, J. Shi, J. Ni, F. Gao, W. Weng, K. Jiao, Electrochimica Acta, 2011, 56, 3829-3834.

[40] M. Zhang, W. Gorski, J. Am. Chem. 2005, 127, 2058-2059.
[41] H. Li, X. Y. Le, D. W. Pang, H. Deng, Z. H. Xu, Z. H. Lin, J. Inorg. Biochem. 2005, 99, 2240-2247.

[42] V. G. Vaidyanathan, B. U. Nair, Eur. J. Inorg. Chem., 2003, 19, 36333638.

[43] V. G. Vaidyanathan, B. U. Nair, Eur. J. Inorg. Chem. 2004, 9, 1840-1846. [44] Q. Wang, X. Wang, Zh. Yu, X. Yuan, K. Jiao, J. Electrochem. Sci., 2011, 6, 5470-5481.

[45] T. Hirohama, Y. Kuranuki, E. Ebina, T. Sugizaki, H. Arii, M. Chikira, P. Tamil Selvi, J. Inorg. Biochem. 2007, 99, 1205-1219.

[46] Y. Zhou, J. Zhao, Y. B. Wu, C. X. Yin, P. Yang, J. Inorg. Biochem. 2010, 101, 10-18.

[47] Q. Li, P. Yang, H. Wang, M. Guo, J. Inorg. Biochem. 1996, 64, 181-195.

[48] M. Zimpl, J. Skopalová, K. Lemr, M. Kotouček, Chemica Acta, 2007, 47. [49] Q. Wang, F. Gao, X. Yuan, W. Li, K. Jiao, Dyes and Pigment,s 2010, 84, 213-217.

[50] Y. Ding, Q. Wang, F. Gao, Electrochimica Acta, 2013, 106, 35-42.

[51] A. Fuhrmann, O. Gans, S. Weiss, G. Haberhauer, M. H. Gerzabe, Water Air Soil Pollut, 2014, 225, 1944-1951.

[52] S. Kowal, P. Balsaa, F. Werres, Anal Bio anal Chem. 2012, 403, 1707-1717.

[53] C. Ghebbioni, M. Trevisan, Pest management science, 1992, 34, 105-107.

[54] A. Tutarli, M. Cici S. Çelik, Environmental Technology, 1995, 16, 995-1000.

[55] M. Zimpl M. Kotouček K. Lemr, J. Veselá, J. Skopalová, J. Fresenius, J Anal Chem, 2001, 371, 975-982.

How to cite this manuscript: Hossein Peyman, Hamideh Roshanfekr, Sahar Ansari. "DNA-based electrochemical biosensor using chitosan-carbon nanotubes composite film for biodetection of Pirazon". Eurasian Chemical Communications, 2020, 2(2), 213-225. 